\title{
Institutional delivery and postnatal care services utilizations in Abuna Gindeberet District, West Shewa, Oromiya Region, Central Ethiopia: A Community-based cross sectional study
}

\author{
Birhanu Darega ${ }^{1 *}$, Nagasa Dida $^{2}$, Fikru Tafese ${ }^{3}$ and Shimeles Ololo ${ }^{3}$
}

\begin{abstract}
Background: Delivery at health institutions under the care of trained health-care providers and utilization of postnatal cares services plays vital roles in promoting child survival and reducing the risk of maternal mortality. More than $80 \%$ of maternal deaths can be prevented if pregnant women access to essential maternity cares like antenatal care, institutional delivery and postnatal care services. Thus, this study aimed to assess institutional delivery and postnatal care services utilizations in Abuna Gindeberet District, West Shewa, Oromiya Regional State, Ethiopia.

Methods: A community-based cross-sectional study design was employed among 703 randomly identified mothers of Abuna Gindeberet district in March, 2013. Data were collected through interviewer-administered questionnaires and analyzed using SPSS version 16.0. Descriptive, bivariate and multivariate analyses were used to determine prevalence and to identify associated factors with institutional delivery and postnatal care, considering $p$-value of less than 0.05 as significant. The results were presented in a narrative forms, tables and graphs.

Results: One hundred one (14.4\%) of mothers gave birth to their last baby in health institutions. From 556 (79.1\%) of respondents who heard about postnatal care services, only $223(31.7 \%)$ of them utilized postnatal care services for their recent childbirth. From the total postnatal care users, 204 (91.5 \%) of them took the services from health extension workers. Decision-making styles, household distances from health institutions, household being model family and ANC services utilizations were found to be statistically significant with both institutional delivery and postnatal care services utilizations. But educational status of husbands was statistically significant with only postnatal care services utilizations.

Conclusions: Both institutional delivery and postnatal care services utilizations from health institutions were low. Decision-making styles, household distances from health institutions, household being model family and ANC services utilizations were the common factors that affect institutional delivery and postnatal care services utilizations from health institutions. Therefore, giving attention to the identified factors could improve and sustain institutional delivery and postnatal care services utilizations from health institutions.
\end{abstract}

Keywords: Institutional delivery, Postnatal care, Associated factors, Abuna Gindeberet district

\footnotetext{
* Correspondence: birhanudarega@yahoo.com

'Department of Nursing, Goba Referral Hospital, Madda Walabu University,

Bale-Goba, Ethiopia

Full list of author information is available at the end of the article
}

\section{$\int$ Biomed Central}

(c) 2016 The Author(s). Open Access This article is distributed under the terms of the Creative Commons Attribution 4.0 International License (http://creativecommons.org/licenses/by/4.0/), which permits unrestricted use, distribution, and reproduction in any medium, provided you give appropriate credit to the original author(s) and the source, provide a link to the Creative Commons license, and indicate if changes were made. The Creative Commons Public Domain Dedication waiver (http://creativecommons.org/publicdomain/zero/1.0/) applies to the data made available in this article, unless otherwise stated. 


\section{Background}

Maternal mortality remains a major challenge to health systems worldwide. Some eight million women suffer from pregnancy-related complications and over half a million die annually. In developing countries, one woman in 11 may die of pregnancy related complications compared to one in 5000 in developed countries [1].

In the sub-Saharan Africa, over 162,000 women still die each year during pregnancy and childbirth. Most of these deaths are because of the lack of access to skilled childbirth attendances and emergency cares [2].

Maternal mortality in Ethiopia is high relative to developed countries and some developing countries. Every year, 500,000 maternal disabilities occur in the country [3]. Maternal mortality ratio (MMR) in 2011 was 676 deaths per 100,000 live births [4].

More than $80 \%$ of maternal deaths can be prevented if pregnant women access essential maternity cares like antenatal care services, institutional delivery that by skilled attendance at childbirth as well as emergency obstetric care and postnatal care services [5]. Institutional delivery services utilizations in Oromiya region was $4.3 \%$ in EDHS 2005 and increased to $8 \%$ in EDHS 2011, which was much lower than the national level. In addition to this, the postnatal care services utilizations was also very low that is $4.8 \%$ in EDHS 2005 and increased to $6.1 \%$ in EDHS $2011[4,6]$. Hence, this study conducted to determine the prevalence of institutional delivery and postnatal care service utilization and their associated factors among Abuna Gindeberet District mothers, Oromiya Regional State, West Shewa Zone, Ethiopia.

\section{Methods}

\section{Study setting and participation}

A community-based cross-sectional study was conducted among 703 women who gave birth in the last 12 months in Abuna Gindeberet district, West Shewa Zone, Oromiya Regional State in March 2013. The district had 42 rural sub-districts from which 14 of them randomly selected. The rationale behind selecting 14 sub-districts over 42 is to include representative sample which mean in some literature of world health organization (WHO), the sample must be between 30 and $50 \%$ of total population. Therefore, we tried to include one-third of the total population [7]. In each selected sub-districts, households with under 1-year children identified through census and sampling frame was developed. Finally, study subjects were addressed through simple random sampling by using sampling frame developed from conducted census data [8]. The sample was determined using single population proportion formula with an assumption of level of confidence of the study $95 \%$, sampling error tolerated $5 \%$ and proportion of institutional delivery care services utilization (P) $50 \%$ used. Design effect of 1.7 and a non-response rate of $10 \%$ were also considered. Design effect 1.5 to 2 is enough in cross sectional study which done in multistage sampling. Depending on the population under study whether the community is homogeneous or heterogeneous we can use starting from 1.5 to 2 design effect. If we consider the community is heterogeneous, we can use design effect 2. Again, if we consider the community is homogeneous, we can use design effect $1.5[9,10]$. According to this, in this study the rural dispersed population is our study. Even though, they are dispersed population, all of them are rural. Two things considered in this condition, being all of them rural makes them homogeneous population and being dispersed population makes them heterogeneous population. Therefore, since these two conditions were present, we used design effect averagely or in middle of the range (because we can use starting from 1.5 up to 2 depending on condition of the population).

\section{Operational definitions}

Postnatal care: the services given to a mother for a period of 6 weeks from the time of delivery in their previous delivery from health institutions.

Decision making style: It is the ways of determining and control over resources when women should seek health care services. The style may be both husband and wife decides together or separately by individual.

Model family: is a family that applied all health extension packages at their home and got certificates of appreciations from health extension workers.

\section{Instruments and data collection methods}

Structured questionnaires, which address the objectives of the study, were adapted from pertinent literatures [11-13, 15-17, 18-20]. The questionnaires translated into the local language - Afan Oromo and retranslated to English. Pre-test was done on $5 \%$ of the sample size in sub districts (kebeles) different from those selected sub-districts for the study before actual data collections. House to house, data collection was made through interviewer-administered questionnaires.

\section{Data processing and analysis}

Data entered into Epidata version 3.1 and exported to SPSS version 16.0 for analysis. Descriptive analysis was done to determine the prevalence of institutional delivery care services and postnatal care services utilizations. Binary and multiple logistic regression analyses by backward conditional method were used to 
identify associated factors with institutional delivery care services and postnatal care services utilizations. Variables that had $p$-value of less than 0.05 by binary logistic regression were included in the multiple logistic regression analysis. A p-value of 0.05 was used as cutoff point to identify statistically significant variables.

\section{Results}

\section{Socio-demographic characteristics of respondents}

A total of 703 mothers were participated in the study with a response rate of $98.7 \%$. The mean age of the respondents was $31.5(\mathrm{SD} \pm 7.34)$ years. Protestant Christianity account for the highest proportion in religion 525 (74.7 \%) followed by Orthodox (17.4\%). Three hundred sixteen (45\%) of the respondents had not attended any form of educations. Six hundred eighty one $(96.9 \%)$ of the respondents were married (Table 1).

\section{Institutional delivery services utilizations}

This study revealed that 101 (14.4\%) women were delivered their recent babies in health institutions and majority of women $602(85.6 \%)$ were delivered at home. Two hundred fourteen $(35.5 \%)$ of home deliveries were attended by mother-in-law, by their mother 138 $(22.9 \%)$ and relatives/neighbors 109 (18.1\%). Only 51 (8.5 \%) of home delivery were assisted by health extension workers. The major reasons for preference of home delivery were history of normal previous home delivery $261(43.4 \%)$ and wanting to stay at home with their relatives 169 (28\%).

Among 101 (14.4\%) mothers that delivered at health institutions, $44(43.6 \%)$ of them reported that they had bad outcome with previous home delivery, 29 (28.7\%) had difficulty in labor and 23 (22.8 \%) need better service were their major reasons for why they preferred delivery at health institutions. From the total mothers interviewed in the study, 498 (70.8 \%) of them had an intention to deliver their newborns at health institutions in the future (Table 2).

\section{Associated factors of institutional delivery service utilizations}

According to this study women who decide by themselves were 2.8 times more likely to utilize delivery care from health institutions $[\mathrm{AOR}=2.859,95 \% \mathrm{CI}=1.56$, 5.22]. Similarly, women that live at the distance of less than $5 \mathrm{~km}$ away from health facility were 9.2 more likely to utilize delivery care from health institutions than those women who live at a distance of greater than $5 \mathrm{~km}$ away from health facility $[\mathrm{AOR}=9.179,95 \% \mathrm{CI}=3.825$, 22.026]. In addition; those respondents who were from model family household were 6.7 times more likely to utilize institutional delivery than respondents who were from non-model family household $[\mathrm{AOR}=6.744,95 \%$ $\mathrm{CI}=4.052$, 11.226]. Those women who use ANC services were also 3.7 times more likely to use institutional delivery services than women who did not use ANC services $[\mathrm{AOR}=3.671,95 \% \mathrm{CI}=1.098,12.275]$.

Age, educational level of respondent and their husband, occupation of respondent and their husband were not statistically associated with institutional delivery services utilizations from health institutions in this study (Table 3).

\section{Postnatal care services utilizations}

Of the total respondents, $556(79.1 \%)$ of them heard about postnatal care services. Two hundred twenty three (31.7\%) respondents utilized the postnatal care services for their recent child and from this, 204 (91.5 \%) of them utilized the services from health extension workers. Two

Table 1 Socio-demographic characteristics of the respondents in Abuna Gindeberet district, West Shewa Zone, Oromiya Region, Central Ethiopia, March, 2013

\begin{tabular}{|c|c|c|c|}
\hline Variables & Alternatives & $\begin{array}{l}\text { Number } \\
(n=703)\end{array}$ & $\begin{array}{l}\text { Percent } \\
(\%)\end{array}$ \\
\hline \multirow[t]{4}{*}{ Educational status } & 1. No education & 316 & 45.0 \\
\hline & 2. Only read and write & 110 & 15.6 \\
\hline & 3. Primary education & 233 & 33.1 \\
\hline & 4. Secondary education & 44 & 6.3 \\
\hline \multirow{2}{*}{$\begin{array}{l}\text { Educational level of } \\
\text { husbands of } \\
\text { respondents }\end{array}$} & 1. Unable to read and write & 174 & 25.6 \\
\hline & 2. Able to read and write & 507 & 74.4 \\
\hline \multirow[t]{3}{*}{ Religion } & 1. Protestant & 525 & 74.7 \\
\hline & 2. Orthodox & 122 & 17.3 \\
\hline & 3. Wakefata & 56 & 8.0 \\
\hline \multirow{2}{*}{$\begin{array}{l}\text { Occupation of } \\
\text { respondents }\end{array}$} & 1. Housewife & 648 & 92.2 \\
\hline & 2. Employed & 55 & 7.8 \\
\hline \multirow{3}{*}{$\begin{array}{l}\text { Occupation of } \\
\text { husband of } \\
\text { respondents }\end{array}$} & 1. Farmer & 547 & 80.3 \\
\hline & 2. Employed & 89 & 13.1 \\
\hline & 3. Merchant & 45 & 6.6 \\
\hline \multirow[t]{2}{*}{ Marital Status } & 1. Married & 681 & 96.9 \\
\hline & 2. Single & 22 & 3.1 \\
\hline \multirow{2}{*}{$\begin{array}{l}\text { Distance of house } \\
\text { from health post }\end{array}$} & 1. $1-5 \mathrm{~km}$ & 461 & 65.6 \\
\hline & 2. $>5 \mathrm{~km}$ & 242 & 34.4 \\
\hline \multirow{4}{*}{$\begin{array}{l}\text { Household status } \\
\text { towards as model } \\
\text { family }\end{array}$} & $\begin{array}{l}\text { 1. Did not hear about } \\
\text { model family }\end{array}$ & 22 & 3.1 \\
\hline & $\begin{array}{l}\text { 2. Have heard but not at all } \\
\text { working towards } \\
\text { graduation }\end{array}$ & 66 & 9.4 \\
\hline & $\begin{array}{l}\text { 3. Working towards } \\
\text { graduation }\end{array}$ & 472 & 67.1 \\
\hline & $\begin{array}{l}\text { 4. Graduated as model } \\
\text { family }\end{array}$ & 143 & 20.3 \\
\hline
\end{tabular}


Table 2 Delivery Services Utilizations in Abuna Gindeberet district, West Shewa Zone, Oromiya Region, Central Ethiopia, March 2013

\begin{tabular}{|c|c|c|c|}
\hline Variables & Alternatives & $\begin{array}{l}\text { Number } \\
(n=703)\end{array}$ & $\begin{array}{l}\text { Percent } \\
(\%)\end{array}$ \\
\hline \multirow[t]{3}{*}{ Place of delivery } & 1. Home & 602 & 85.6 \\
\hline & $\begin{array}{l}\text { 2. Health center and } \\
\text { Hospital }\end{array}$ & 34 & 4.9 \\
\hline & 3. Health post & 67 & 9.5 \\
\hline \multirow{6}{*}{$\begin{array}{l}\text { Person assisted for } \\
\text { home delivery }\end{array}$} & 1. Mother-in-law & 214 & 35.5 \\
\hline & 2. Relatives/neighbors & 109 & 18.1 \\
\hline & 3. Mother & 138 & 22.9 \\
\hline & $\begin{array}{l}\text { 4. Health extension } \\
\text { workers }\end{array}$ & 51 & 8.5 \\
\hline & 5. Health professionals & 7 & 1.2 \\
\hline & $\begin{array}{l}\text { 6. Traditional birth } \\
\text { attendant }\end{array}$ & 83 & 13.8 \\
\hline \multirow[t]{5}{*}{$\begin{array}{l}\text { Reason for home } \\
\text { delivery }\end{array}$} & $\begin{array}{l}\text { 1. Facility not opens } \\
\text { regularly }\end{array}$ & 52 & 8.7 \\
\hline & $\begin{array}{l}\text { 2. Poor quality service of } \\
\text { HFs }\end{array}$ & 76 & 12.6 \\
\hline & $\begin{array}{l}\text { 3. Need to be with } \\
\text { relatives }\end{array}$ & 169 & 28 \\
\hline & $\begin{array}{l}\text { 4. Previous home deliver } \\
\text { was normal }\end{array}$ & 261 & 43.4 \\
\hline & $\begin{array}{l}\text { 5. I was told my } \\
\text { pregnancy is normal }\end{array}$ & 44 & 7.3 \\
\hline \multirow{4}{*}{$\begin{array}{l}\text { Reason for delivering } \\
\text { at health facility }\end{array}$} & 1. Need better service & 23 & 22.8 \\
\hline & $\begin{array}{l}\text { 2. Bad outcome with } \\
\text { previous home deliver. }\end{array}$ & 44 & 43.6 \\
\hline & 3. Difficulty during labor. & 29 & 28.7 \\
\hline & 4. Others & 5 & 4.9 \\
\hline \multirow{3}{*}{$\begin{array}{l}\text { Decision maker at } \\
\text { home }\end{array}$} & 1. The mother herself & 79 & 11.3 \\
\hline & 2. Her husband & 61 & 8.7 \\
\hline & 3. Both of them & 563 & 80.0 \\
\hline \multirow{3}{*}{$\begin{array}{l}\text { Place of delivery for } \\
\text { the next newborn }\end{array}$} & 1. At home & 193 & 27.5 \\
\hline & $\begin{array}{l}\text { 2. Traditional birth } \\
\text { attendant }\end{array}$ & 12 & 1.7 \\
\hline & 3. Health institutions & 498 & 70.8 \\
\hline
\end{tabular}

hundred twelve $(30.2 \%)$ of the respondents who utilized postnatal care for their recent child were from mothers who gave birth at their home. Three hundred (42.7\%) respondents said that if the problem resulted after delivery on the baby, they will go to health institutions (Table 4).

\section{Associated factors of postnatal care service utilizations}

In this study women who used ANC services were 4.9 times more likely to use postnatal care services than women who did not use ANC services for their recent child (AOR $=4.956,95 \% \mathrm{CI}=2.506,9.80)$. Women who able decide by themselves were 2.3 times more likely to utilize postnatal care from health institutions [AOR = $2.319,95 \% \mathrm{CI}=1.825,6.520]$. Similarly, women that live at the distance of less than $5 \mathrm{~km}$ away from health facility were 2.3 times more likely to utilize postnatal care from health institutions than those respondents who live at greater than $5 \mathrm{~km}$ away from health facility $[\mathrm{AOR}=$ $2.320,95 \% \mathrm{CI}=1.557,3.455]$. In addition; respondents who were from household that become model family were found to be 3 times more likely to utilize postnatal care services than respondents from households that were not model family $[\mathrm{AOR}=2.970,95 \% \mathrm{CI}=1.985$, 4.444].

Age, educational level of respondent, occupation of respondent and their husband were not associated with postnatal care services utilization from health institutions in this study (Table 5).

\section{Discussion}

This article has tried to assess institutional delivery and postnatal care services utilization and their associated factors among mothers of under 1 year children. From the total study participants, only $101(14.4 \%)$ of them delivered their youngest child in health institutions. Among the home delivery, 214 (35.5\%) attended by mother-in-law, $138(22.9 \%)$ attended by their mother, $109(18.1 \%)$ attended by relatives/neighbors and 51 (8.5 \%) assisted by HEWs.

In case of the study done in Tigray region, Ethiopia; 691 (95.3 \%) of women delivered their baby at home with the help of relative/friend/neighbor 586 (80.8\%) and $49(6.8 \%)$ were assisted by the HEWs [11]. In addition, the study conducted in Sekela District, North West of Ethiopia; indicated that 326 (87.9 \%) of the mothers delivered at home with the assistance of family members 274 (80 \%), themselves 20 (6.1\%), their mother $13(3.98 \%)$ and health workers $2(0.6 \%)$ [12].

Moreover, the study done in in Munisa district, South East Ethiopia show that, 750 (87.7 \%) of the mothers gave birth to their last baby at home by the assistance of family or relatives $392(52.2 \%)$, untrained traditional birth attendant $288(38.4 \%)$, themselves $23(3.1 \%)$ and no one were assisted by health workers during their home delivery [13].

The delivery services utilizations from health institutions can be affected by distance of household from health institution, household as model family, decisionmaking style in household and utilization of ANC services.

In contrary to this finding, in study done at Wukro and Butajera districts, Ethiopia; the factors that determine use of institutional delivery were women education and household economic status. However, women's autonomy in decision making on place of delivery did not 
Table 3 Institutional delivery services utilization and associated factors from health institutions in Abuna Gindeberet District, West Shewa Zone, Oromiya Region, Central Ethiopia, March, 2013

\begin{tabular}{|c|c|c|c|c|c|}
\hline \multirow[t]{2}{*}{ Socio demographic } & \multirow[t]{2}{*}{ Alternatives } & \multicolumn{2}{|c|}{$\begin{array}{l}\text { Institutional delivery service } \\
\text { utilizations }\end{array}$} & \multirow[t]{2}{*}{ COR [95 \% C.I] } & \multirow[t]{2}{*}{ AOR $[95 \%$ C.I] } \\
\hline & & Yes & No & & \\
\hline \multirow[t]{3}{*}{ Age of respondents } & $18-24$ years & 17 & 117 & $0.750(0.0 .410-1.373)$ & \\
\hline & $25-34$ years & 41 & 263 & $0.805(0.506-1.280)$ & \\
\hline & 35 and above & 43 & 222 & 1.00 & \\
\hline \multirow[t]{2}{*}{ Educational level of respondents } & Unable to read and write & 38 & 278 & 1.00 & \\
\hline & Able to read and write & 63 & 324 & $1.423(0.922-2.194)$ & \\
\hline \multirow[t]{3}{*}{ Decision making styles } & Wife & 33 & 46 & $5.496(3.279-9.212)$ & $2.859(1.565-5.223)^{*}$ \\
\hline & Husband & 3 & 58 & $0.396(0.396-1.301)$ & $0.467(0.133-1.639)$ \\
\hline & Both together & 65 & 498 & 1.00 & 1.00 \\
\hline \multirow[t]{2}{*}{ Educational level of husbands of respondents } & Unable to read and write & 28 & 146 & 1.00 & \\
\hline & Able to read and write & 73 & 434 & $2.142(1.358-3.379)$ & \\
\hline \multirow[t]{2}{*}{ Model family } & Not model & 39 & 521 & 1.00 & 1.00 \\
\hline & Model family & 62 & 81 & $10.225(6.430-16.262)$ & $6.744(4.052-11.226)^{*}$ \\
\hline \multirow[t]{2}{*}{ Occupation of respondent } & Housewife & 87 & 561 & 1.00 & \\
\hline & Employed & 14 & 41 & $1.022(1.556-2.879)$ & \\
\hline \multirow[t]{3}{*}{ Occupation of husbands of respondents } & Farmer & 79 & 468 & 1.00 & \\
\hline & Employed & 13 & 76 & $1.022(0.544-1.920)$ & \\
\hline & Merchant & 9 & 36 & 2. $013(1.736-3.179)$ & \\
\hline \multirow[t]{2}{*}{ Household distance from health institutions } & $1-5 \mathrm{~km}$ & 97 & 364 & $9.721(4.191-22.546)$ & $9.179(3.825-22.026)^{*}$ \\
\hline & $>5 \mathrm{~km}$ & 7 & 235 & 1.00 & 1.00 \\
\hline \multirow[t]{2}{*}{ Have you used ANC } & Yes & 98 & 481 & 8.218 (2.561-26.370) & $3.671(1.098-12.275)^{*}$ \\
\hline & No & 3 & 121 & 1.00 & 1.00 \\
\hline
\end{tabular}

${ }^{*} p<0.001$

Table 4 Postnatal care Services Utilizations in Abuna Gindeberet district, West Shewa Zone, Oromiya Region, Central Ethiopia, March 2013

\begin{tabular}{|c|c|c|c|}
\hline Variables & Alternatives & Number $(n=703)$ & Percent (\%) \\
\hline \multirow[t]{2}{*}{ Ever heard of postnatal care } & 1. Yes & 556 & 79.1 \\
\hline & 2. No & 147 & 20.9 \\
\hline \multirow[t]{2}{*}{ Used PNC in the recent delivery } & 1. Yes & 223 & 31.7 \\
\hline & 2. No & 480 & 68.3 \\
\hline \multirow[t]{3}{*}{ Place of PNC used } & 1. Health post & 204 & 91.5 \\
\hline & 2. Other health institutions & 13 & 5.9 \\
\hline & 3. Traditional birth attendant & 6 & 2.6 \\
\hline \multirow[t]{2}{*}{ Visited by health worker immediately after delivery of your recent child } & 1. Yes & 212 & 30.2 \\
\hline & 2. No & 491 & 69.8 \\
\hline \multirow[t]{3}{*}{ The health workers visited you during recent delivery } & 1. Health extension worker & 167 & 78.6 \\
\hline & 2. Traditional birth attendant & 41 & 19.3 \\
\hline & 3. Health professionals & 4 & 2.1 \\
\hline \multirow[t]{5}{*}{ Health facilities you visit if any problems after birth } & 1. Stay home & 23 & 3.3 \\
\hline & 2. Traditional healers & 78 & 11.1 \\
\hline & 3. Health post & 300 & 42.7 \\
\hline & 4. Other health institutions & 235 & 33.4 \\
\hline & 5. Religious place & 67 & 9.5 \\
\hline
\end{tabular}


Table 5 Association of factors with postnatal care services utilizations in Abuna Gindeberet District, West Shewa Zone, Oromiya Region, Central Ethiopia, in March, 2013

\begin{tabular}{|c|c|c|c|c|c|}
\hline \multirow[t]{2}{*}{ Socio demographic } & \multirow[t]{2}{*}{ Alternatives } & \multicolumn{2}{|c|}{$\begin{array}{l}\text { Postnatal care services } \\
\text { utilizations }\end{array}$} & \multirow[t]{2}{*}{ COR [95 \% C.I] } & \multirow[t]{2}{*}{ AOR [95 \% C.I] } \\
\hline & & Yes & No & & \\
\hline \multirow[t]{3}{*}{ Age of respondent } & $18-24$ years & 38 & 96 & $1.235(0.784-1.946)$ & \\
\hline & $25-34$ years & 98 & 206 & $1.027(0.723-1.460)$ & \\
\hline & 35 and above & 87 & 178 & 1.00 & \\
\hline \multirow[t]{2}{*}{ Educational level of respondent } & Unable to read and write & 98 & 218 & 1.00 & \\
\hline & Able to read and write & 125 & 262 & $0.942(0.684-1.297)$ & \\
\hline \multirow[t]{3}{*}{ Decision making style } & Wife & 32 & 47 & $6.241(2.402-16.217)$ & $2.319(1.825-6.520)^{* *}$ \\
\hline & Husband & 6 & 55 & $1.391(0.859-2.254)$ & $0.835(0.486-1.436)$ \\
\hline & Both together & 185 & 378 & 1.00 & 1.00 \\
\hline \multirow[t]{2}{*}{ Educational level of husbands of respondents } & Unable to read and write & 29 & 145 & 1.00 & \\
\hline & Able to read and write & 194 & 313 & $2.950(1.824-4.771)$ & \\
\hline \multirow[t]{2}{*}{ Model family } & Not model & 139 & 421 & 1.00 & \\
\hline & Model family & 84 & 59 & $4.312(2.937-6.332)$ & \\
\hline \multirow[t]{2}{*}{ Occupation of respondents } & Housewife & 206 & 442 & $1.281(0$ 0.797-2.058) & \\
\hline & Employed & 17 & 38 & 1.00 & \\
\hline \multirow[t]{3}{*}{ Occupation of husbands of respondents } & Farmer & 172 & 375 & 1.00 & \\
\hline & Employed & 37 & 52 & $1.637(1.038-2.582)$ & \\
\hline & Merchant & 14 & 31 & $3.492(1.681-4.078)$ & \\
\hline \multirow[t]{2}{*}{ Household distance from health institutions } & $1-5 \mathrm{~km}$ & 172 & 289 & $2.229(1.552-3.201)$ & $2.320(1.557-3.455)^{* *}$ \\
\hline & $>5 \mathrm{~km}$ & 51 & 191 & 1.00 & 1.00 \\
\hline \multirow[t]{2}{*}{ Have you used ANC } & Yes & 210 & 369 & $6.634(3.401-12.941)$ & $4.956(2.506-9.80)^{* *}$ \\
\hline & No & 13 & 111 & 1.00 & 1.00 \\
\hline \multirow[t]{2}{*}{ Institutional delivery for recent baby } & yes & 60 & 41 & $3.941(2.549-6.095)$ & $1.853(1.101-3.120) * *$ \\
\hline & No & 163 & 439 & 1.00 & 1.00 \\
\hline
\end{tabular}

${ }^{*} P<0.003$

show statistical association [14]. Moreover, according to the study conducted in Dodota district, Oromiya regional state, Ethiopia; residence, educational level of mothers, pregnancy related health problems, previous history of prolonged labor, and decision making style showed association with utilization of institutional delivery services utilizations [15].

Concerning the postnatal care services 223 (31.7\%) of the respondents utilized the services for their recent child. From those had utilized postnatal care services for their last child, 204 (91.5\%) of them took the services from health extension workers. This result is congruent with study done in Sidama zone, Southern Ethiopia; where $37.2 \%$ of the mothers utilized postnatal care services from health institutions [16]. To the contrary, in Tigray region, Ethiopia; only $5 \%$ of the mothers had PNC checkups for their baby at health institutions [11].

Postnatal care services utilization from health institution can be affected by educational status of their husband, household distance from health institution, household as model family, decision making style, ANC services utilization and place of recent delivery. In similar educational status, women's autonomy, number of pregnancy and place of delivery were the factors making a difference in utilizing post natal care service [16]. Confidence and knowledge from previous pregnancies and births were the major reasons for low utilization of postnatal care services among many child holder women.

In this study interviewer administered method of data collection used, that has contribution for quality of data collected. The data were collected from representative sample and it can be generalized for the total population. Only quantitative methods of data collection were used and it is better if qualitative methods were included to triangulate the information collected from the sample.

\section{Conclusions}

Both institutional delivery and postnatal care services utilizations from health institutions were low. Decisionmaking style, household distance from health institutions, household being model family and ANC services 
utilization were found to be statistically significant with both institutional delivery and postnatal cares service utilizations. Educational status of respondents' husband is found to be statistically significant with only postnatal care services utilization from health institutions.

Thus, focusing these identified factors for individual variables could improve and sustain institutional delivery and postnatal care services utilizations from health institutions simultaneously.

\section{Abbreviations}

ANC, antenatal care; AOR, adjusted odd ratio; COR, crude odd ratio; Cl, confidence interval; EDHS, Ethiopian Demographic and Health Survey; HEWs, health extension workers; HF, health facilities; PNC, postnatal care.

\section{Acknowledgements}

We would like to thank Jimma University that, this research would not have been possible without the financial support of it. Our thanks also extend to all staffs of Abuna Gindeberet District Health Office, especially Mr. Worku Kenani Benti (Head of district health office) who facilitated the conditions for data collection activities, data collectors and study participants.

\section{Authors' contributions}

$\mathrm{BD}, \mathrm{FT} \& \mathrm{SO}$ were involved in the conception, design, analysis, interpretation and report writing. ND assisted the analysis and manuscript preparation. BD prepared the manuscript. BD \& ND critically reviewed the manuscript. All authors have read and approved this manuscript.

\section{Competing interests}

The authors declare that they have no competing interests.

\section{Ethics approval and consent to participate}

Ethical clearance and approval were obtained from the Ethical Review Committee of the College of Public Health and Medical Sciences, Jimma University. Permission was obtained from district Health Office. Oral informed consents were obtained from participants. Confidentiality and anonymity were ensured. Participants were informed that their participations were voluntary.

\section{Author details}

'Department of Nursing, Goba Referral Hospital, Madda Walabu University, Bale-Goba, Ethiopia. ${ }^{2}$ Department of Public Health, Goba Referral Hospital, Madda Walabu University, Bale-Goba, Ethiopia. ${ }^{3}$ Department of Health Service Management, College of Public Health and Medical Sciences, Jimma University, Jimma, Ethiopia.

Received: 29 July 2014 Accepted: 23 June 2016

Published online: 07 July 2016

\section{References}

1. Villar J, Bergsjo P. Pattern of routine antenatal care for low-risk pregnancy Cochrane Review. 2004. http://www.apps.who.int/rhl/reviews/langs/ CD000934.pdf

2. Tsegay $Y$ et al. Determinants of antenatal and delivery care utilization in Tigray region, Ethiopia: a cross-sectional study. Int J Equity Health. 2013;12: 30. doi: 10.1186/1475-9276-12-30

3. Gemechu A. One national plan, the Ethiopian experiences, and Global business plan for MDG 4 and 5. Ethiopia, Geneva: FMOH; 2010. http://www. who.int/pmnch/events/2007/gbpgemechu.pdf.

4. Central Statistical Agency: ICF International: Ethiopian Demographic and Health Survey. Addis Ababa, Ethiopia, Calverton, Maryland, USA; 2012. http://www.unicef.org/ethiopia/ET_2011_EDHS.pdf.

5. WHO, Maternal health and safe motherhood progress report update. Geneva; 2009.

6. CSA and ORC Macro. Ethiopia Demographic and Health Survey 2005. Addis Ababa, Ethiopia and Calverton, Maryland, USA: Central Statistical Agency and ORC Macro; 2006. http://www.www.unicef.org/ethiopia/DHS_2005 Ethiopia.pdf.
7. Omi S. Health research methodology: a guide for training in research methods. 2nd ed. Manila: World Health Organization. Regional Office for the Western Pacific; 2001. ISBN 929061157 X.

8. Central Statistical Agency of Ethiopia. Socio-Economic and demographic Profile of Abuna Gindeberet District. 2011. http://www.csa.gov.et/ newcsaweb/images/documents/pdf_files/regional/Oromya1.pdf.

9. Bierrenbach W. Calculating the sample size for surveys of the prevalence of Tuberculosis. Combodia. August 2006. http://www.tbrieder.org/publications/ books_english/who_prevalence_surveys.pdf.

10. Turner AG. Sampling Topics for Disability Surveys. United Nations Statistics Division, Technical Notes. 1996. http://www.undp.org/popin/demotss/ tcndec96/tony.htm.

11. Medhanyie A et al. The role of health extension workers in improving utilization of maternal health services in rural areas in Ethiopia: a cross sectional study. BMC Health Serv Res. 2012;12:352. doi: 10.1186/1472-6963-12-352.

12. Teferra AS et al. Institutional delivery service utilization and associated factors among mothers who gave birth in the last 12 months in Sekela District, North West of Ethiopia: a community-based cross sectional study. BMC Pregnancy Childbirth. 2012;12:74. doi: 10.1186/1471-2393-12-74.

13. Amano A et al. Institutional delivery service utilization in Munisa Woreda, South East Ethiopia: a community based crosssectional study. BMC Pregnancy Childbirth. 2012:12:105. doi: 10.1186/1471-2393-12-105.

14. Hagos $S$ et al. Utilization of institutional delivery service at Wukro and Butajera districts in the Northern and South Central Ethiopia. BMC Pregnancy Childbirth. 2014;14:178. doi: 10.1186/1471-2393-14-178.

15. Fikre AA, Demissie M. Prevalence of institutional delivery and associated factors in Dodota Woreda (district), Oromia regional state, Ethiopia. Reprod Health. 2012;9:33. doi:10.1186/1742-4755-9-33.

16. Workineh $Y G$, Hailu DA. Factors affecting utilization of postnatal care service in Amhara Region, Jabitena District, Ethiopia. Science Journal of Public Health. 2014;2(3):169-76. doi:10.11648/j.sjph.20140203.15.

17. Aminah K. Factors determining utilization of postpartum care services in Uganda. 2010

18. Warren C, Mekbib T. Reviewing maternal mortality in rural Ethiopia by using the verbal autopsy approach, Addis Ababa, Ethiopia. Ethiop J Reprod Health. 2009;3(3): 4-14.

19. Mesfin N, Damen H, Getnet M. Assessment of Safe Delivery Service Utilization among women of child bearing age in North Gondar Zone. Ethiop J Health Dev. 2004;18(3):146-50.

20. Paudel M, Khanal V, Acharya B, Adhikari M. Determinants of Postnatal Service utilization in a Western District of Nepal: Community Based Cross Sectional Study. J Women's Health Care. 2013;2:126. http://dx.doi.org/10. 4172/2167-0420.1000126.

Submit your next manuscript to BioMed Central and we will help you at every step:

- We accept pre-submission inquiries

- Our selector tool helps you to find the most relevant journal

- We provide round the clock customer support

- Convenient online submission

- Thorough peer review

- Inclusion in PubMed and all major indexing services

- Maximum visibility for your research

Submit your manuscript at www.biomedcentral.com/submit 